\title{
CRITICAL THINKING IN HIGHER EDUCATION STUDY PROGRAMS: CASE STUDY
}

\author{
Jolanta Pivoriene \\ Mykolas Romeris University, Lithuania
}

\begin{abstract}
Social work in its essence has direct relation with critical thinking what is expressed in the Global definition of social work. It is one of the professions which need immediate reaction to unexpected changes in uncertain situations; therefore, it is relevant to discuss critical thinking contribution to the development of social work profession and its presence in social work education. The aim of the article is to discuss importance of critical thinking in higher education and to present data of case study, which reveals how critical thinking is expressed in social work education. Case study was done in country's one university. Descriptions of all social work study programs subjects' descriptions were analysed using quantitative and qualitative content data analysis. The analysis of social work study programs at selected university revealed that critical thinking is more expressed in master level than bachelor level social work study programs and it is more described as domain- specific then domain-general, is mentioned in learning outcomes and assessment and very rarely - study methods. The case study identified the gap between formality and reality. Theoretically critical thinking should be part of social work study programs; however, it is wide possibilities for enhancing critical thinking manifestation in the reality of teaching and learning.
\end{abstract}

Keywords: competences, critical thinking, higher education, social work study programs.

\section{Introduction}

Importance of critical thinking in higher education is emphasized in international and national policy documents (UNESCO, 2009; The European Higher Education Area, 2012; OECD, 2016; World Economic Forum, 2016; Council of the European Union, 2018; Lietuvos Respublikos Seimo nutarimas, 2012) and various research (Elen et al., 2019; Indrašiene et al., 2018; Indrašiene et al., 2019; Indrašiene et al., 2020; Kazlauske, 2020; Penkauskiene et al., 2020). In classical critical thinking theoretical approach, it is described as "a liberating force in education and a powerful resource in one's personal and civic life" (Facione, 1990, p.3).

Critical thinking becomes very important in dealing with complex, uncertain, evolving and urgent situations when rapid changes call for timely reactions which should be addressed by making sustainable decisions. Social work is one of the professions which need immediate reaction to unexpected changes in uncertain 
situations; therefore, it is relevant to discuss critical thinking contribution to the development of social work profession and its presence in social work education.

The aim of the article is to discuss importance of critical thinking in higher education and to present data of case study, which reveals how critical thinking is expressed in social work education. Country's one university was chosen for case study. It was conceptualised and designed according to Elen \& al. (2019) framework - one of the leading documents about critical thinking in higher education which declares that in order to support the development of critical thinking, it has to be a goal of education and to manifest at three levels: institutional, teaching program and course. The last two levels are presented in the article by discussing qualitative and quantitative data of descriptions of all social work study programs and study subjects at that university.

\section{Critical Thinking in Social Work Higher Education - Theoretical Approach}

Emphasis on critical thinking and its expansion in research started from Delphi project when American Philosophical Association commissioned forty-six experts in critical thinking teaching, research, assessment in natural and social sciences, education, and philosophy to participate in the two years project. According to their consensus statement in executive summary, critical thinking is understood „to be purposeful, self-regulatory judgment which results in interpretation, analysis, evaluation, and inference, as well as explanation of the evidential, conceptual, methodological, criteriological, or contextual considerations upon which that judgment is based" (Facione, 1990, p. 3). Six cognitive core skills of critical thinking were defined in the document: interpretation, analysis, evaluation, inference, explanation and self-regulation. Later on, this initial consensus evolved, split in various approaches, perspectives, theoretical schools (Indrasiene et al., 2019), but always was defined as essential tool of inquiry.

Since Delphy project plenty of studies about critical thinking in higher education were done, mentioning chronologically few but not all most known: Siegel, 1988; Barnett, 1997; Halpern, 1998; Paul \& Elder, 2001; Andrews, 2007; Badcock, Pattison \& Harris, 2010; Lim, 2011; Ku, Ho, Hau \& Lai, 2014; Liu, Frankel \& Roohr, 2014; Davies, 2015; Loes \& Pascarella, 2017. Connection of critical thinking and social work education was investigated at less extend but still various research could be named: Plath, English, Connors \& Beveridge, 1999; Coleman, Rogers \& King, 2002; Gibbons \& Gray, 2004; Heron, 2006; Sheppard \& Charles, 2014; Mathias 2015; Sharma 2015; Samson 2016; Sheppard, \& Charles, 2017; Samson, 2018; Sheppard, Charles, Rees, Wheeler, \& Williams, 2018. Investigations at national level (Gudzinskiene, 2006; Rimienè, 
2006; Ubartaite-Vingiene, 2007; Tolutiene \& Domarkiene, 2010; Penkauskiene, 2016; Indrašienė et al., 2018; Penkauskiene et al, 2020) analysed critical thinking on more general level, paying little attention specifically to the critical thinking in social work education.

Social work in its essence has direct relation with critical thinking what is expressed in the Global definition of social work. In its core mandate it is written that „the development of critical consciousness through reflecting on structural sources of oppression and/or privilege, on the basis of criteria such as race, class, language, religion, gender, disability, culture and sexual orientation, and developing action strategies towards addressing structural and personal barriers are central to emancipatory practice where the goals are the empowerment and liberation of people" (https://www.ifsw.org/what-is-social-work/globaldefinition-of-social-work/). And it is once more emphasized in Principles saying that "constructive confrontation, deconstruction and change may be facilitated through a tuning into, and an understanding of particular cultural values, beliefs and traditions and via critical and reflective dialogue with members of the cultural group vis-à-vis broader human rights issues" (https://www.ifsw.org/what-issocial-work/global-definition-of-social-work/). It is obvious then that social work education needs to include not only learning professional skills but also core cognitive critical thinking skills using information from different sources and respecting the dignity and diversity of vulnerable people (Samson, 2016). Sheppard \& Charles (2017) add that professional social worker could successfully cope with challenging situations only using intellectual endeavors and critical thinking in searching for solutions in a complex and multifaceted environment.

\section{Methodology}

Case study was chosen to use in research. Usually case study is described as an empirical inquiry that investigates a contemporary phenomenon within its real time context (Rubin \& Babbie, 1993) and is chosen in order to understand and explain specific cases, when case could be described as having clear boundaries (Creswell, 2014). Sampling university for inclusion in the case study these criteria were applied: social work study programs implemented at bachelor and master levels, social work study programs are suggested for full time and part time studies, study programs accredited not earlier than two years, there is open access to a full study program description. At selected university at the moment of the research in 2020, there were four study programs awarding degree in social work: 1 bachelor (full-time and part time) and 3 master ( 1 full-time and 2 part-time) level (see Table 1). 
Pivoriene, 2021. Critical Thinking in Higher Education Study Programs: Case Study

Table 1 Social Work Study Programs

\begin{tabular}{|l|l|l|l|l|}
\hline Acronym & SWB & SWM & SWChRM & SWChYM \\
\hline Level & Bachelor & Master & Master & Master \\
\hline Duration in years & $\begin{array}{l}\text { 4 full/5part } \\
\text { time }\end{array}$ & 2 part time & 2 part time & 1,5 full time \\
\hline Study language & national & national & national & English \\
\hline No of subjects & 46 & 18 & 14 & 15 \\
\hline
\end{tabular}

Bachelor (SWB) and one master (SWM) level study programs were of generalist social work, two other master level study programs (SWChRM, SWChYM) were specialised and prepared graduates to work with specific vulnerable groups. One master level study program was taught in English, all the rest in national language.

In total there were 93 study subjects in all study programs: 46 in bachelor and 47 in master level study programs. Descriptions of all study subjects constituted the final array of sampling. Search key word „kritin*” was applied for screening all study subjects' descriptions. Then descriptions were read by researcher for checking if „kritin*” is used to describe critical thinking or another item. Only these study subjects' descriptions which had connection with critical thinking were left for analysis: 29 in bachelor and 31 in master study programs.

In the next step qualitative and quantitative content analysis were applied for the analysis of study subjects' descriptions. Quantitative content analysis aims to provide numerically based summary of a chosen message set, it summarizes rather than reports all details concerning a message set (Neuendorf, 2017) while qualitative content analysis allows to understand the meaning behind the data (Maxwell, 2008). In data analysis process, firstly, using quantitative content analysis, share of study subjects with critical thinking was calculated according to study years and semesters, obligatory and elective courses. Secondly, using qualitative content analysis, it was searched in what structural parts of study subject description and how (in what wording) critical thinking is mentioned.

\section{Critical Thinking in Social Work Study Programs' Descriptions - Findings}

Quantitative data analysis of bachelor level study program shows that the biggest share of study subjects with critical thinking is in the $4^{\text {th }}$ study year (70.00\%), the lowest - in the $2^{\text {nd }}$ year $(46.15 \%)$. The $1^{\text {st }}$ and the $3^{\text {rd }}$ years are similar, having $53.33 \%$ and $57.14 \%$ respectively. Looking more specifically to subjects' share in semesters, the critical thinking is most often found in the seventh (83.33\%), the fifth (62.50\%) and the first (54.14\%) semesters. It could be assumed that critical thinking in the seventh semester as final semester before writing thesis, and in the first semester which includes more general then 
professional study subjects, could be reasonable. However, there is no clear explanation why the fifth semester has so strong emphasis on critical thinking. Further research interviewing program's developers, teachers and students would probably clarify the situation. Another finding is that critical thinking is more expressed in the obligatory (56.52\%) then in the elective (37.50 \%) more general education courses what leads to the assumption that critical thinking in social work study program manifests more as domain-specific then domain-general what supports ideas of McPeck (1990), Garside (1996), Moore (2011), Tiruneh et al. (2016) who assume that critical thinking better could be learnt in the context of a specific study field.

Qualitative data analysis showed that critical thinking is expressed in learning outcomes, study methods and assessment (Table 2).

Critical thinking is mentioned in assessment (in 15 study subjects) and learning outcomes (in 11 study subjects) more often than in study methods (in 8 study subjects), however, there is difference in describing learning outcomes and assessment or study methods. If learning outcomes encompass more content information, critical thinking in assessment and study methods is described in standard stencil way. Assessment of making critical remarks is the main choice of study subject descriptions' developers. Assessment of the formulation of critical comments and insights, self-critical approach is mentioned episodically. In all except one study subjects where critical thinking is mentioned in study methods - critical thinking stimulating study methods - is used. The exception is one study subject which applies the method of critical analysis of intolerance.

Presentations of learning outcomes provide more understanding about critical thinking. The most prevailing critical thinking competence is evaluation (of the phenomena of reality, scientific and philosophical thought, social discourses, knowledge, theoretical approaches and their strengths and weaknesses, real practical situations, goals and measures of welfare policy) what is close to Ennis (1987), Beyer (1987) definitions which emphasis the evaluation of assumptions, causes and opinions. Then follows analysis (of situations, critical processes', scientific information) which is described in Facione (1990), Halpern (1998), Beyer (1987), Siegel (1988) sense. Reasoning is mentioned in one study subject's description. There are several cases in which critical thinking as such ability to think critically - is mentioned. In all learning outcomes critical thinking is defined as cognitive skills in its classical understanding (Facione, 1990). 
Table 2 Critical Thinking in Bachelor Study Subjects' Descriptions

\begin{tabular}{|c|c|c|}
\hline No. & Description & Type \\
\hline 1. & $\begin{array}{l}\text { To develop the ability to critically evaluate the phenomena of } \\
\text { reality, scientific and philosophical thought, social discourses, } \\
\text { knowledge. } \\
\text { The method of critical analysis of intolerance is applied } \\
\text { The provision of critical remarks is assessed. }\end{array}$ & $\begin{array}{l}\text { Study methods } \\
\text { Assessment }\end{array}$ \\
\hline 2. & $\begin{array}{l}\text { To evaluate critically social work theoretical approaches, their } \\
\text { strengths and weaknesses }\end{array}$ & Learning outcomes \\
\hline 3. & Ability to reason/to think critically & Learning outcomes \\
\hline 4. & $\begin{array}{l}\text { To critically evaluate the theoretical approaches of social } \\
\text { work, their strengths and weaknesses, to evaluate the } \\
\text { provision of critical remarks }\end{array}$ & Learning outcomes \\
\hline 5. & $\begin{array}{l}\text { Critically and constructively identify, analyse and solve } \\
\text { situations of legal and social significance, critically evaluate } \\
\text { and correctly solve real practical situations in social work }\end{array}$ & Learning outcomes \\
\hline 6. & The aim is to develop the student's critical thinking & Learning outcomes \\
\hline 7. & $\begin{array}{l}\text { The ability to critically evaluate the goals and measures of } \\
\text { welfare policy }\end{array}$ & Learning outcomes \\
\hline 8. & Development of critical analytical thinking & Learning outcomes \\
\hline 9. & Critical processes' analysis & Learning outcomes \\
\hline 10. & Ability to think critically & Learning outcomes \\
\hline 11. & Ability to analyse critically & Learning outcomes \\
\hline 12. & $\begin{array}{l}\text { Critical analysis of scientific information. } \\
\text { Methods that stimulate critical thinking are applied. }\end{array}$ & $\begin{array}{l}\text { Learning outcomes } \\
\text { Study methods }\end{array}$ \\
\hline 13. & Critical thinking stimulating study methods are used & Study methods \\
\hline 14. & Critical thinking stimulating study methods are used & Study methods \\
\hline 15. & Critical thinking stimulating study methods are used & Study methods \\
\hline 16. & $\begin{array}{l}\text { Critical thinking stimulating study methods are used } \\
\text { Making critical remarks }\end{array}$ & $\begin{array}{l}\text { Study methods } \\
\text { Assessment }\end{array}$ \\
\hline 17. & $\begin{array}{l}\text { Students are given critical thinking stimulating tasks. } \\
\text { The formulation of critical comments, the formulation of } \\
\text { critical insights, making critical remarks. }\end{array}$ & $\begin{array}{l}\text { Study methods } \\
\text { Assessment }\end{array}$ \\
\hline 18. & $\begin{array}{l}\text { Critical thinking stimulating study methods are used } \\
\text { Making critical remarks }\end{array}$ & $\begin{array}{l}\text { Study methods } \\
\text { Assessment }\end{array}$ \\
\hline $19-29$ & Making critical remarks & Assessment \\
\hline
\end{tabular}

Differences in critical thinking description in learning outcomes, study methods and assessment partly could be explained by structure and requirements of template. Study subject description usually has a standardised template and there is no much freedom of wording, however, choosing and including critical thinking in assessment and study methods should be reasoned and justified. There are very few study subjects which include combination of study methods and assessment or study methods and learning outcomes and only one which demonstrates cohesion of learning outcomes, study methods and assessment. 
Quantitative data of master level study programs is presented in Table 3.

Table 3 Share of Subjects with Critical Thinking (\%)

\begin{tabular}{|l|c|c|c|}
\hline & SWM & SWChRM & SWChYM \\
\hline 1 year & 81.82 & 66.67 & 75.00 \\
\hline 2 year & 57.14 & 40.00 & 100.00 \\
\hline 1 semester & 100.00 & 60.00 & 100.00 \\
\hline 2 semester & 50.00 & 75.00 & 57.14 \\
\hline 3 semester & 66.67 & 50.00 & 100.00 \\
\hline 4 semester & 0.00 & 0.00 & Not applicable \\
\hline Obligatory courses & 66.67 & Not applicable & 75.00 \\
\hline Elective courses & 83.33 & Not applicable & 66.67 \\
\hline
\end{tabular}

Research data shows that bigger share of study subjects with critical thinking is in the $1^{\text {st }}$ study year (SWM - 81.82\%, SWChRM - 66.67\%) in the study programs taught in national language. Master level social work study program taught in English put bigger emphasis on critical thinking in the $2^{\text {nd }}$ year - all study subjects $(100.00 \%)$ include critical thinking. Such situation could be explained by different duration of studies as study program in English is more intense and is implemented in 1.5 years. Data shows that study program taught in English by local and foreign teachers for national and international students in itself has a bigger emphasis on critical thinking thus allowing to assume that international dimension is a stronger prerequisite for critical thinking then local national context. The difference also is seen in the obligatory and the elective courses' shares. There are more elective study subjects with critical thinking in study program taught in national language (83.33\%), but more obligatory study subjects with critical thinking in study program taught in English language (75.00\%).

The same as in bachelor level study program data analysis showed that critical thinking in master level study program is expressed in learning outcomes, study methods and assessment differently. Critical thinking in relation with study methods is mentioned only once in the study subjects of all three programs. Critical thinking in assessment is included much more often in study programs taught in national language and only in rare cases in study program taught in English which contrary to others put a very big emphasis on critical thinking in learning outcomes.

Out of six cognitive skills defined in Delphy report (Facione, 1990) two of them are mentioned in all three programs. The most dominating skill is analysis, at less extend but also in all programs evaluation skill is included. Interpretation, inference, explanation and self-regulation are absent in study subjects' descriptions. 
As was said earlier, teachers should follow template, however, examples of qualitative data show that teachers could describe and emphasise critical thinking in specific sentences in outcomes (for ex., critically analyze modern social work theories theories), study methods (for ex., stimulating critical thinking) and assessments (for ex., the provision of critical comments is assessed). In comparison with bachelor level study program in master level study programs critical thinking is more often mentioned in assessment then learning outcomes.

In summary, content analysis of social work study programs at selected university revealed that critical thinking is more expressed in master level than bachelor level social work study programs and it is more described as domainspecific then domain-general. It is mentioned in learning outcomes and assessment and very rarely - study methods. Analysis and evaluation as cognitive critical thinking skills are clearly inscribed in learning outcomes: evaluation dominates in bachelor and analysis in master level study programs. Assessment usually is presented in very general and abstract terms. Inconsistency of the content in study subjects' descriptions allows assuming that including critical thinking in social work study programs is more coincident then conscious endeavour.

\section{Conclusions}

Even the importance of critical thinking is emphasised in international and national education policy documents, however its manifestation in study programmes is not so obvious.

The case study identified the gap between formality and reality. At the study program level there is no clear description of critical thinking as integral part of the studies. At the course level there are some descriptions of critical thinking as an important learning outcome, however, more vaguely explaining how they can be realized. Further investigation is needed for the discussion about critical thinking at the institutional level - is there a clear mission statement recognising critical thinking as an important goal.

Theoretically critical thinking should be part of social work study programs; however, there are wide possibilities for enhancing critical thinking manifestation in the reality of teaching and learning.

\section{References}

Andrews, R. (2007). Argumentation, Critical Thinking and the Postgraduate Dissertation. Educational Review, 59(1), 1-18.

Badcock, P. B. T., Pattison, P. E., \& Harris, K. L. (2010). Developing generic skills through university study: a study of arts, science and engineering in Australia. Higher Education, 60 (4), 441-458. 
Barnett, R. (1997). Higher education: a critical business. Buckingham, Open University Press. Beyer, B. K. (1987). Practical Strategies for the Teaching of Thinking. Boston, MA: Allyn and Bacon.

Coleman, H., Rogers, G., King, J. (2002). Using portfolios to stimulate critical thinking in social work education. Social Work Education, 21(5), 583-595.

Council of the European Union. (2018). Council Recommendation on Key Competences for Lifelong Learning. Brussels, 23 May, 9009/18. Retrieved from https://eur-lex.europa.eu/ legalcontent/EN/TXT/PDF/?uri=CONSIL:ST_9009_2018_INIT\&from=EN

Creswell, J.W. (2014). A Concise Introduction to Mixed Methods Research. SAGE publications.

Davies, M. (2015). A Model of Critical Thinking in Higher Education. In Paulsen (ed.), Higher Education: Handbook of Theory and Research, p. 41-88.

Elen, J., Jiang, L., Huyghe, S., Evers, M., Verburgh, A., Palaigeorgiou, G. (2019). Promoting Critical Thinking in European Higher Education Institutions: towards an educational protocol. Vila Real: UTAD.

Ennis, R. H. (1987). A taxonomy of critical thinking dispositions and abilities, in: J. Baron \& R. Sternberg (Eds) Teaching thinking skills: theory and practice. New York, Freeman.

Facione, P. A. (1990). Critical thinking: A statement of expert consensus for purposes of educational assessment and instruction. Research findings and recommendations. Fullerton: California State University

Facione, P.A. (1990). The Delphy Report. Executive Summary of Critical Thinking: A Statement of Expert Consensus for Purposes of Educational Assessment and Instruction.

Garside, C. (1996). Look who's talking: a comparison of lecture and group discussion teachingstrategies in developing critical thinking skills, Communication Education, 45, 212-227

Gibbons, J., Gray, M. (2004). Critical thinking as integral to social work practice. Journal of Teaching in Social Work, 24(1/2), 19-38.

Gudzinskiene, V. (2006). Kritinio mąstymo įvairios interpretacijos ir jų analizè. Pedagogika, 81, 107-114.

Halpern, D. F. (1998). Teaching critical thinking for transfer across domains: Dispositions, skills, structure training, and metacognitive monitoring. American Psychologist, 53, 449-455.

Heron, G. (2006). Critical thinking in social care and social work: searching student assignments for the evidence. Social Work Education, 25(3), 209-224.

Indrašienè, V., Jegelevičienė, V., Merfeldaite, O., Penkauskienė, D., Pivorienė, J., Railienė, A., Sadauskas, J., Valavičienè, N. (2020). The Critically Thinking Employee: Employers' point of view. Entrepreneurship and Sustainability Issues, 7(4), 2590-2603.

Indrašienè, V., Jegelevičienė, V., Merfeldaite, O., Penkauskienė, D., Pivorienė, J., Railienė, A., Sadauskas, J., Valavičienè, N. (2019). What critical thinking and for what? Social welfare: interdisciplinary approach, 1 (9), 24-38.

Indrašienè, V., Jegelevičienè, V., Merfeldaite, O., Penkauskienė, D., Pivorienė, J., Railienė, A., Sadauskas, J., ir Valavičienè, N. (2018). Kritinio mąstymo sampratos interpretacijos. Socialinis darbas, 16(2), 266-278.

Jones, S., Ališauskienè, S., Miltenienè, L. (2008). Learning to be critical thinkers: comparative case study of training for future professionals in social field in Lithuania and United Kingdom. Social Sciences, 2(60), 81-89.

Kazlauske S. (2020). Kritinio mastymo ugdymas socialiniu darbuotoju rengime. Magistro baigiamasis darbas. Vinius: Mykolo Romerio universitetas. 
Ku, K. Y. L.;Ho, I. T.; Hau K.\& Lai, E. C. M. (2014). Integrating direct and inquiry-based instruction in the teaching of critical thinking: an intervention study. Instructional Science, 42, 251-269.

Lietuvos Respublikos Seimo nutarimas. (2012). Dèl valstybès pažangos strategijos „,Lietuvos pažangos strategija „Lietuva 2030“ patvirtinimo. Nr. XI-2015 2012 m. gegužès 15 d.

Lim, L. (2011). Beyond logic and argument analysis: Critical thinking, everyday problems and democratic deliberation in Cambridge International Examinations' thinking skills curriculum. Journal of Curriculum Studies, 43, 783-807.

Liu, O. L., Frankel, L., \& Roohr, K. C. (2014). Assessing critical thinking in higher education: Current state and directions for next-generation assessment (Research Report No. RR14-10). Princeton, NJ: Educational Testing Service. 10.1002/ets2.12009

Loes, Ch. N., Pascarella, E. (2017). Collaborative Learning and Critical Thinking: Testing the Link. The Journal of Higher Education, 88(5), 1-27.

Mathias, J. (2015). Thinking like a social worker: examining the meaning of critical thinking in social work. Journal of Social Work Education, 51, 457-474.

Maxwell, J. A. (2008). Designing a qualitative study. The SAGE handbook of applied social research methods. SAGE publications.

McPeck, J. (1990). Teaching critical thinking: Dialogue and dialectic. New York: Routledge.

Moore, T. (2011). Critical thinking and disciplinary thinking: A continuing debate. Higher Education Research \& Development, 30(3), 261-274.

Neuendorf, K. A. (2017). The Content analysis guidebook. SAGE publications.

OECD. (2016). Global competency for an inclusive world.

Paul, R. \& Elder, L. (2001). Critical thinking: Tools for taking charge of your learning and your life. Upper Saddle River: Prentice Hall.

Penkauskiene, D. (2016). Kritinio ir kūrybinio mąstymo sąsaja. Socialine teorija, empirija, politika ir praktika, 13, 90-104.

Penkauskienė, D., Valavičienè, N., Pivorienė, J., Railienè, A., Merfeldaitė, O., Indrašienè, V., Sadauskas, J., Jegelevičienė, V. (2020). Critical thinking embeddedness in higher education programmes. Journal of education culture and society, 11(02), 121-132

Plath, D., English, B., Connors, L., Beveridge, A. (1999). Evaluating the outcomes of intensive critical thinking instruction for social work students. Social Work Education, 18(2), 207-217.

Rimienè, V. (2006). Studentų kritinio mąstymo dispozicijų ir ịūdžių kaitos galimybès. Acta Pedagogica Vilnensia, (17), 78-85.

Rubin, A., Babbie E. (1993). Research methods in social work. 2nd ed. California: Brooks/Cole Publishing Company.

Samson, P. L. (2016). Critical thinking in social work education: a research synthesis. Journal of Social Work Education, 52(2), 147-156.

Samson, P. L. (2018). Critical thinking in social work education: a Delphi study of faculty understanding. Doctoral Dissertation. Windsor: University of Windsor.

Sharma, S. (2015). Fieldwork supervision: meeting requirements of social work education through critical thinking. The Hong Kong Journal of Social Work, 49(1/2), 3-14.

Sheppard, M., Charles, M. (2014). Critical thinking and interpersonal dispositions in those commencing social work training. British Journal of Social Work, 44, 2057-2066.

Sheppard, M., Charles, M. (2017). A longitudinal comparative study of the impact of the experience of social work education on interpersonal and critical thinking capabilities. Social Work Education, 36(7), 745-757. 
Sheppard, M., Charles, M., Rees, P., Wheeler, M., Williams, R. (2018). Inter-personal and critical-thinking capabilities in those about to enter qualified social work: a six-centre study. British Journal of Social Work, 48(7), 1855-1873.

Siegel, H. (1988) Educating reason: rationality, critical thinking and education. New York, Routledge.

The European Higher Education Area. (2012). Bologna process implementation report. Retrieved from http://www.ehea.info/media.ehea.info/file/2012_Bucharest/79/5/ Bologna_Process_Implementation_Report_607795.pdf.

Tiruneh, D., Weldeslassie, A., Kassa, A., Tefera, Z., Cock, M., \& Elen, J. (2016). Systematic design of a learning environment for domain-specific and domain-general critical thinking skills. Educational Technology Research \& Development, 64(3), 481-505.

Tolutiene, G., Domarkiene, J. (2010). Learning Needs and the Possibilities of their satisfaction: the Case of Prospective Andragogues. Tiltai. Socialiniai mokslai, 1 (50, 147-158.

Ubartaite-Vingiene, D. (2007). Kritinio mastymo ugdymas formaliajame suaugusiuju svietime: teorija ir jos praktinis taikymas istorijos pamokose. Vilnius: Versus Aureus.

UNESCO. (2009). The New Dynamics of Higher Education and Research for Societal Change and Development. Paris: UNESCO.

World Economic Forum. (2016). New vision for education: Fostering social and emotional learning through technology. 